\title{
SERPULA ANGUINA.
}

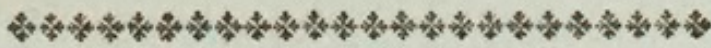

ChARACTER Genericus.

Animal Terebella.

Testa univalvis, tubulosa, adhærens,

(sæpe

isthmis integris passim intercepta.)

$$
\text { Lin. Syst. Nat. p. } 1264 .
$$

CHARACTER SPECIFICUS, Ë.

SERPULA testa teretiuscula subspirali, fissura longitudinali subarticulata.

Lin. Syst. Nat. p. $126 \%$.

List. conch. t. 548. f. 2.

Gualt. test. t. 10. f. z.

Genus quod Serpula dicitur incolunt animalia a reliquis testaceis longe diversa, et quibus nonnulla esse videtur affinitas cum Aphroditis et Nereidibus apud Mollusca ; et Scolopendris apud Insecta. Plurimorum tamen manca et incerta est notitia; nec adhuc descripsit aliquis incolam speciei de qua jam loquimur. Ipsius testæ mira omnino est conformatio. Tubus nempe e quo constat, quique in diversis speciminibus varias subit coloris et inflexionis vices, insignitur per totam longitudinem rima seu fissura, qua continuam exhibet parvorum et oblongorum foraminum. E maribus extrahitur Indicis Serpula anguina. 



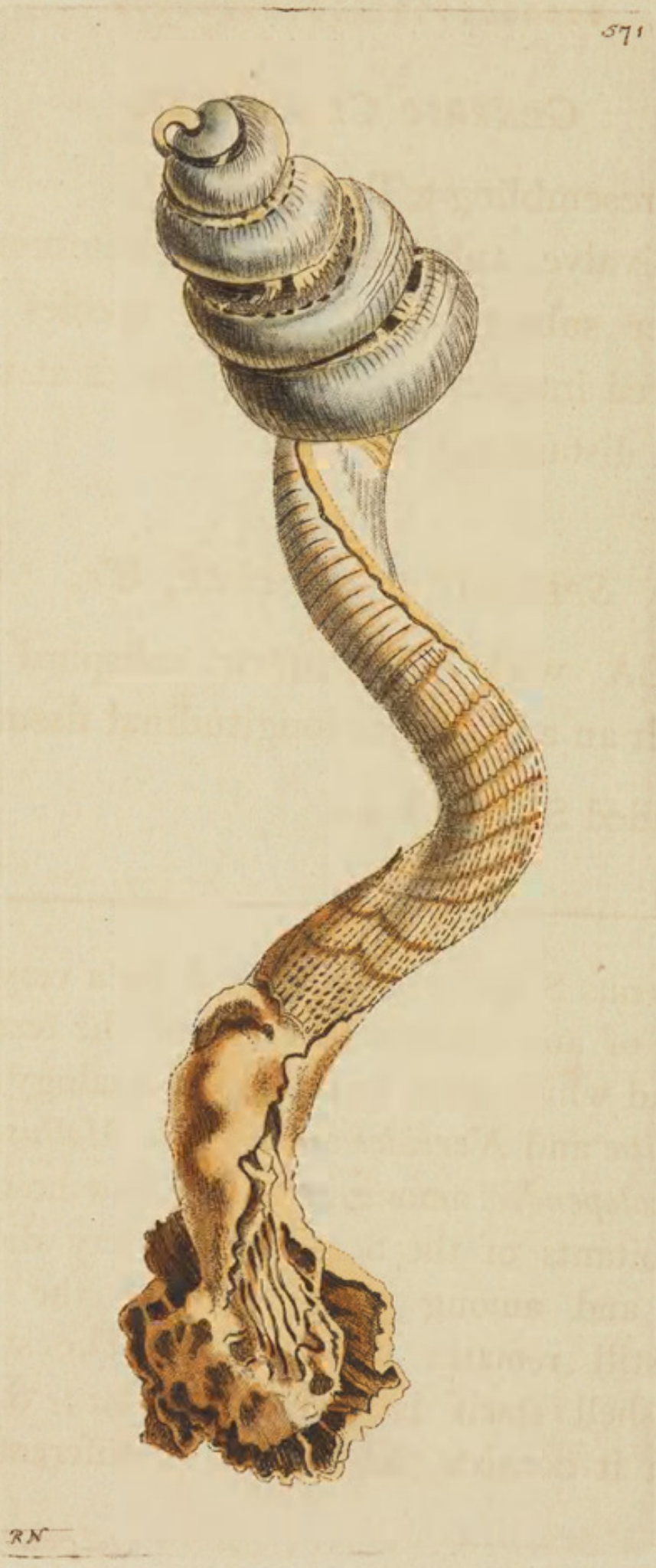




\section{ANGUINE SERPULA.}

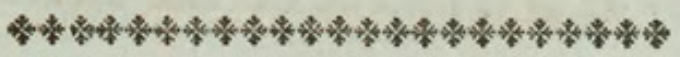

\section{GENERIC CHARACTER.}

Animal resembling a Terebella.

Shell univalve, tubular, adhering commonly to other substances, (in many species intercepted internally by dissepiments at uncertain distances.)

SPECIFIC CHARACTER, छૃ.

SERPULA with subcylindric subspiral shell, with an articulated longitudinal fissure.

Chain-Sided SERPULA.

The genus Serpula is inhabited by a very different race of animals from the rest of the testaceous tribe, and which seem to bear some analogy to the Amphitritce and Nereides among the Mollusca, and to the Scolopendrce among Insects. Few however of the inhabitants of the Serpulæ are very distinctly known, and among others that of the present species still remains undescribed. The structure of the shell itself is highly singular; the tube of which it consists, and which in different speci- 
mens exhibits considerable diversities of flexure and colour, being marked throughout its whole length by a fissure formed of a continued series of oblong perforations. It is a native of the Indian seas. 


\section{$2 \mathrm{BHL}$ Biodiversity Heritage Library}

Shaw, George. 1803. "The Anguine Serpula, Serpula anguina [PI. 571]." The Naturalist's Miscellany 14(CLXIV), https://doi.org/10.5962/p.311015.

View This Item Online: https://www.biodiversitylibrary.org/item/278723

DOI: https://doi.org/10.5962/p.311015

Permalink: https://www.biodiversitylibrary.org/partpdf/311015

\section{Holding Institution}

Museums Victoria

\section{Sponsored by}

Atlas of Living Australia

\section{Copyright \& Reuse}

Copyright Status: Public domain. The BHL considers that this work is no longer under copyright protection.

This document was created from content at the Biodiversity Heritage Library, the world's largest open access digital library for biodiversity literature and archives. Visit BHL at https://www.biodiversitylibrary.org. 